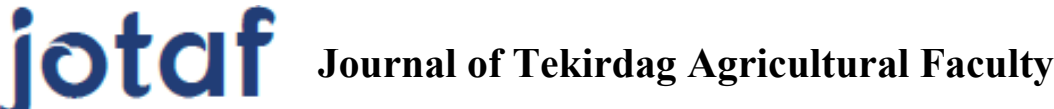

Mayis/May 2021, 18(2)

\section{Yulaf Çim Suyunun Bazı Yabancı Ot ve Kültür Bitkisi Tohumlarının Çimlenme ile Fide Özellikleri Üzerine Etkileri}

Effects of Oat Grass Juice on Germination and Seedling Characteristics of Certain Weeds and Cultivated Plants

\section{Ruziye KARAMAN ${ }^{*}$, Cengiz TÜRKAY ${ }^{2}$, İlknur AKGÜN ${ }^{3}$}

\section{Özet}

Çalışma, Isparta Uygulamalı Bilimler Üniversitesi Ziraat Fakültesi Tarla Bitkileri laboratuvarında 2020 yılında, yulaf çim suyunun bazı kültür bitkisi ve yabancı ot tohumlarının çimlenme ve fide gelişimi üzerine etkilerini belirlemek amacıyla kurulmuştur. Çalışmada kültür bitkileri olarak arpa, buğday, yulaf, fasulye, mercimek, şeker pancarı, ayçiçeği, İtalyan çimi, kırmızı üçgül ve yonca tohumları; yabancı ot tohumu olarak ise, horozibiği ve yabani hardal tohumları kullanılmıştır. Çalışma, tesadüf parselleri deneme deseninde 4 tekerrürlü olarak yürütülmüş̧ür. Uygulama olarak tohumlara yulaf çim suyu ve santrifüj edilmiş yulaf çim suyunun farklı dozları $(\% 25,50,75$ ve 100) yapılmıştır. Araştırmada çimlenme oranı, çimlenme indeksi, ortalama çimlenme süresi, sürgün ve kök uzunluğu ile yaş ve kuru ağırlık özellikleri incelenmiştir. Denemede çimlenme oranları fasulyede \% 33.59-90.0; mercimekte $\% 0-76.8$; arpada $\% 0-71.6$; buğdayda $\% 0-77.9$; yulafta $\% 0-55.6$; ayçiçeğinde $\% 11.5-90.0$ ve yoncada \%36.16-68.20 olarak belirlenmiștir. Çimlenme indeksi fasulyede 1.08-6.62; mercimekte 0-16.04; arpada 0-13.96; buğdayda 0-6.93; yulafta 0-6.88; ayçiçeğinde 0.19-7.31 ve yoncada 2.93-10.28 arasında değişmiştir. Sürgün uzunluğu fasulye hariç, mercimek, arpa ve yulaf bitkilerinde; kök uzunluğu ise mercimek, arpa, buğday ve yulafta \%25 santrifüj edilmiş yulaf çim suyu (YÇS) uygulaması ve kontrol gruplarında belirlenmiştir. Artan santrifüj edilmiş YÇS dozları ve YÇS uygulamaları ile bazı türlerde (ayçiçeği ve yonca) çimlenme olmuş ancak sürgünler ölçüm yapılamayacak kadar küçük olması sebebiyle sürgün ve kök uzunluğu belirlenememiş olup, buna paralel olarak yaş ve kuru ağırlıkları tespit edilememiştir.

Elde edilen verilere göre, çimlenme ve fide gelişimi üzerine yulaf çim suyu uygulaması ve artan santrifüj edilmiş çim suyu dozlarının etkisinin olumsuz olduğu belirlenmiştir. Yulaf çim suyunun mineral madde, vitaminler, protein ve antioksidan içerikleri yönünden zengin olmasına rağmen, tohum çimlenmesi ve fide gelişiminde doğrudan bioaktivatör olarak kullanılamayacağı belirlenmiştir. Yulaf çim suyunun içerdiği birçok allelopatik etkiye sahip maddeler (saponin (avenacins), hidroxamik asit, skopoletin, L-triptofan ) tohum çimlenmesini engellemiştir.

Anahtar Kelimeler: Yulaf çim suyu, Çimlenme, Çimlenme indeksi, Fide gelişimi, Allelopati

\footnotetext{
1*Sorumlu Yazar/Corresponding Author: Ruziye KARAMAN, Isparta Uygulamalı Bilimler Üniversitesi Ziraat Fakültesi Tarla Bitkileri Bölümü, Isparta ve Türkiye. E-mail: ruziyekaraman@isparta.edu.tr (iD) OrcID: 0000-0001-5088-8253.

${ }^{2}$ Cengiz TÜRKAY, Isparta Uygulamalı Bilimler Üniversitesi Ziraat Fakültesi Tarla Bitkileri Bölümü, Isparta ve Türkiye. E-mail: cengiz3370turkay@gmail.com (iD) OrcID: 0000-0003-3857-0140.

${ }^{3}$ İlknur AKGÜN, Isparta Uygulamalı Bilimler Üniversitesi Ziraat Fakültesi Tarla Bitkileri Bölümü, Isparta ve Türkiye. E-mail: ilknurakgun@isparta.edu.tr (ib OrcID: 0000-0002-7476-7226.

Atıf/Citation: Karaman, R., Türkay, C., Akgün, İ. (2020). Yulaf Çim Suyunun Bazı Yabancı Ot ve Kültür Bitkisi Tohumlarının Çimlenme ile Fide Özellikleri Üzerine Etkileri. Tekirdağ Ziraat Fakültesi Dergisi, 18 (2), 312-321.
} 


\begin{abstract}
The study was carried out to determine the effects of oat grass juice on certain culture plants and weeds seeds germination and seedling growth at the Isparta University of Applied Sciences, Faculty of Agriculture, Field Crops Laboratory in 2020. Barley, wheat, oat, bean, lentils, sugar beet, sunflower, Italian ryegrass, crimson clover and alfalfa seeds as cultivated crops; cockscomb and wild mustard seeds as weed seed were used in the study. The study was established to completely randomized plot design with four replications. As application, oat grass juice and centrifuged oat grass juice doses $(25,50,75$ and 100\%) were applied to these seeds. In the research, germination rate, germination index, mean germination time, shoot and root length, and wet and dry weight properties were examined. The germination rates in the experiment were $33.59-90.0 \%$ in beans; $0-76.8 \%$ in lentils; $0-71.6 \%$ in barley; $0-77.9 \%$ in wheat; $0-55.6 \%$ in oats; $11.5-90.0 \%$ in sunflower and $36.2-68.2 \%$ in alfalfa. Germination index changed between 1.08-6.62 in beans; 0-16.04 in lentils; 0-13.96 in barley; 0-6.93 in wheat; 06.88 in oats; It varied between $0.19-7.31$ in sunflower and 2.93-10.28 in crimson clover. Shoot length except for beans, lentil, barley and oat plants, root length were determined for lentil, barley, wheat and oat plants in $25 \%$ centrifuged oat grass juice (OGJ) application and control groups. Germination occurred in some species (sunflower and alfalfa) with increasing centrifuged OGJ doses and OGJ applications, but the shoot and root length could not be determined because the seedlings were too small to be measured, and in parallel, their wet and dry weights could not be determined.

According to the data obtained, it was determined that oat grass juice application and increasing centrifuged grass juice doses had negative effects on germination and seedling development. Although oat grass juice is rich in mineral substance, vitamins, protein and antioxidant content, it has been determined that it cannot be directly used as a bioactivator in seed germination and seedling development. Many substances with allelopathic effects (saponin (avenacins), hydroxamic acid, scopoletin, L-tryptophan) contained in oat grass juice prevented seed germination.
\end{abstract}

Keywords: Oat grass juice, Germination, Germination index, Seedling development, Allelopathy 


\section{Giriş}

Serin iklim tahılları tohumlarından elde edilen çimin sağılı için yararı ile ilgili tartışmalar son 15-20 yıldır gündeme gelmektedir. Amerika'da 1930'lardan itibaren tahıl çimleri şişelenmiş veya kurutulmuş halde tüketilmeye başlanmıştır. Yapılan çalışmalar sonucunda, tahıl çimlerinin, tahıl unlarına oranla 4-5 kat fazla vitamin, mineral ve protein içerdikleri belirlenmiştir (Sezgin, 2020).

Günlük beslenmede her öğünde tüketilen un mamulleri genellikle tahıllardan karşılanmakta ve tahıllardan istenilen besin değerini elde etme amacıyla çeşitli yöntemler (çimlendirme, fermantasyon ve 1 sıl işlem vb.) kullanılmaktadır (Finney, 1982). Tahılların çimlendirilmesi ile yüksek miktarda antioksidan aktivitesine sahip ürünler ortaya çıkmakta (Rexhepi ve Renata, 2015a) ve bu yeşil ürünler insan sağlığı üzerine yararlı olduğu bildirilmektedir (Ashish ve ark., 2012). Bunlara ek olarak beyin fonksiyonları bozuk olan yaşlı kişiler üzerinde yapılan iki çalışmada diyetlerinde 800-1600 mg yulaf çim suyu takviyesi ile hafiza, dikkat ve konsantrasyonu önemli ölçüde iyileştirdiği tespit edilmiştir (Berry ve ark., 2011; Kennedy ve ark., 2017).

Birçok araştırmada çim sularının yeşil gıda, bitki büyüme düzenleyicisi, herbisit ve fungusit vb., alanlarda kullanım performansları belirlenmiştir (Ergün, 2011; Karaşahin, 2015; Akgün ve ark., 2018 a;b). Serin iklim tahılları içerisinde özellikle yulaf çim suyu demir içeriği bakımından diğerlerinden daha üstündür. Bir kişinin günlük alması gereken demir miktarı $10 \mathrm{mg}$ 'dır. Bir çay bardağı $(100 \mathrm{~g})$ yulaf çim suyunda ise, $13.6 \mathrm{mg}$ demir bulunmaktadır (Demirci, 2009; Ergün, 2011). Ergün (2011), yulaf çim suyunun mineral içeriğini belirlediği çalışmada, günde 100 gr yulaf çim suyu içildiği takdirde günlük gerekli olan mineral madde ihtiyacının $\mathrm{P} \% 6.4$, $\mathrm{Ca} \%$ 3.7, $\mathrm{Mg} \%$ 6.8, Na \% 2, K \% 3.65, Cu \% 16, Fe \% 80, Mn \% 4, Zn \% 15'inin karşılanacağını ifade etmiştir. Rexhepi ve Renata (2015b), yulaf çim suyunun zengin aminoasit içeriği yanında önemli vitaminleri (B1, 2, 6, ve 12) de bünyesinde bulundurduğunu ve ayrıca yulaf çim suyunun mineraller, vitaminler, antioksidanlar (tricin), klorofiller ile enzimler yönünden oldukça zengin olduğunu bildirmişlerdir. Çim sularının içerdiği etken maddeler (saponin, protein ve aminoasit) sebebiyle diğer bir kullanım alanı tohumlar üzerindeki allelopatik etkisidir. Allelopati, bitkide çeşitli organlar tarafından salgılanan sekonder metabolitlerin etkileşime girerek bitki gelişmesini önlemesi ya da durdurması olarak tanımlanmaktadır (Reigosa ve ark., 2002; Oueslati, 2003; Lam ve ark., 2012; Gürsoy ve ark., 2013). Allelopatiye neden olan etkili bileşiklere allelokimyasal adı verilmektedir. Bu bileşikler genellikle bitkilerde bulunan sekonder metabolitlerden oluşmaktadır (Oudhia, 2000; Ghiyasi ve ark., 2016). Sekonder metabolitler bitkide fiziyolojik ve ekofiziyolojik etkide bulunmaktadır. Allelopatik maddeler iki şekilde bulunmaktadır. Bunlardan ilki; bitkilerin parçalanması ile (inaktif allelopati), ikincisi kök veya gövdeden ortama salgılanma (aktif allelopati) şeklinde olmaktadır (Ghiyasi ve ark., 2016). Allelopati üzerine pek çok çalışma bulunmaktadır (Karaman ve ark, 2014; Ghiyasi ve ark., 2016; Akgün ve ark., 2018 a;b).

Terzi (2007), ceviz meyve kabuklarının suyunu (homojenizatörden geçirdikten sonra santrifüj edilmiş halini) kavun tohumlarına uygulamış ve çimlenme ile fide gelişimi üzerine etkisini belirlemiştir. Araştırıcı 1/4 oranında seyreltilmiş ceviz meyve kabuğu özütlerinin, fide gelişimi üzerine olumlu etkide bulunurken, saf ve 1/8 oranında seyreltilmiş özütler ise fide gelişimini önemli seviyede olumsuz olarak etkilemiştir. Karaman ve ark. (2014), lavanta bitkisinden elde ettikleri uçucu yağın dozlarının kültür ve yabancı bitkiler üzerine etkilerini araştırdıkları çalışmada lavanta yağının dozlarının artması ile çimlenme ve fide özelliklerinde düşüşler meydana geldiğini ifade etmişlerdir. Ghiyasi ve ark. (2016), sirken yabancı otunun \%6'lık bitki özütü dozlarının (\%20, 40, 80 ve 100) kolza tohumlarının çimlenme ve anormal çim oluşturma özellikleri üzerine etkilerini incelemişlerdir. Sonuç olarak araştırmacılar, \%100 oranında sirken bitki özütünün en düşük çimlenme ve en yüksek anormal fide yüzdesine neden olduğunu ifade etmişlerdir. Akgün ve ark. (2018a), buğday çim suyunun mısırda fide gelişimi üzerine aktivatör olma potansiyelini ve Rhizoctonia solani üzerine etkilerini belirledikleri çalışmada, buğday çim suyunun mısırda fide gelişimi üzerine olumsuz etkide bulunduğunu belirtmişlerdir. Ayrıca, mısırda buğday çim suyunun Rhizoctonia solani semptomlarının şiddetini arttırdığını tespit etmişlerdir. Ergin ve Kaya (2020), yulaf bitki özütü dozlarının yağ bitkileri tohumlarının çimlenme ve fide gelişimi üzerine etkilerini belirledikleri çalışmada, yağ bitkileri tohumlarının çimlenme süresinin artan yulaf bitki özütü dozları ile uzadığını ve fide gelişimi üzerine yulaf bitki özütünün artan dozlarının olumsuz etkide bulunduğunu saptamışlardır. Hatta araştırmacılar, yulaf bitki özütü artan dozlarının buğday ve yulaf fideleri gelişimini engellediğini ifade etmişlerdir. Yulaf bitkisinde de allelopatik etkiye hidroxamik asit, skopoletin, L-triptofan maddelerinin neden olduğu bildirilmiştir (Gürsoy ve ark., 2013). Diğer taraftan bazı triterponoid olan saponinlerin (avenacin) kültürü yapılan tahıllarda hastalıklara dayanıklılığın 
geliştirilmesinde etkili olabileceği ileri sürülmüş̧ür (Osbourn, 2003). Kuca ve Yağcı (2021), bilinçsiz pestisit kullanılmasının ürünlerde ilaç kalıntısı kalmasına neden olduğunu bu nedenle de, çevre ve insan sağlığı yönünden risk oluşturduğunu bildirmişlerdir. Bu durum göz önüne alınarak, birçok bitkinin çim suyu çıkarılmış ve kalıntı bırakmayan pestisit (herbisit ve fungusit vb.) olarak kullanım performansları belirlenmiştir.Bu çalışmada yulaf çim suyu ve santrifüj edilmiş yulaf çim suyu (süparnatant) dozlarının bazı yabancı ot ve kültür bitkileri tohumlarının çimlenmesi ve fide gelişimi üzerine etkilerini belirlemek amaçlanmıştır.

\section{Materyal ve Yöntem}

Araştırma, Isparta Uygulamalı Bilimler Üniversitesi Ziraat Fakültesi Tarla Bitkileri Laboratuvarında 2020 yılında yapılmıştır. Çalışmada bazı kültür bitkileri ve yabancı ot tohumları kullanılmışıtır. Kültür bitkisi olarak; iki sıralı arpa (Hordeum vulgare), ekmeklik buğday (Triticum aestivum L.), yulaf (Avena sativa L.), fasulye (Phaseolus vulgaris L.), mercimek (Lens culinaris), şeker pancarı (Beta vulgaris), ayçiçeği (Helianthus annuus L.), İtalyan çimi (Lolium multiforum Lam.), kırmızı üçgül (Trifolium incarnatum L.) ve yonca (Medicago sativa L.), yabanc1 ot tohumu olarak ise, horoz ibiği (Amaranthus albus L.) ve yabani hardal (Sinapis arvensis L.) tohumları kullanılmıştır. Çalışma, tesadüf parselleri deneme deseninde 4 tekerrürlü olarak kurulmuştur. Denemede toplam [4 tekerrür x 12 tür x 6 uygulama (kontrol ve yulaf çim suyu konsantrasyonları)] 288 petri kullanılmıştır (Şekil 1). Her bir bitki türü için 6 farklı uygulama [saf su (kontrol), yulaf çim suyu (YÇS) ve santrifüj edilmiş yulaf çim suyunun (YÇS) 4 farklı konsatrasyonu (\%25, \%50, \%75 ve \%100)] yapılmıştır.
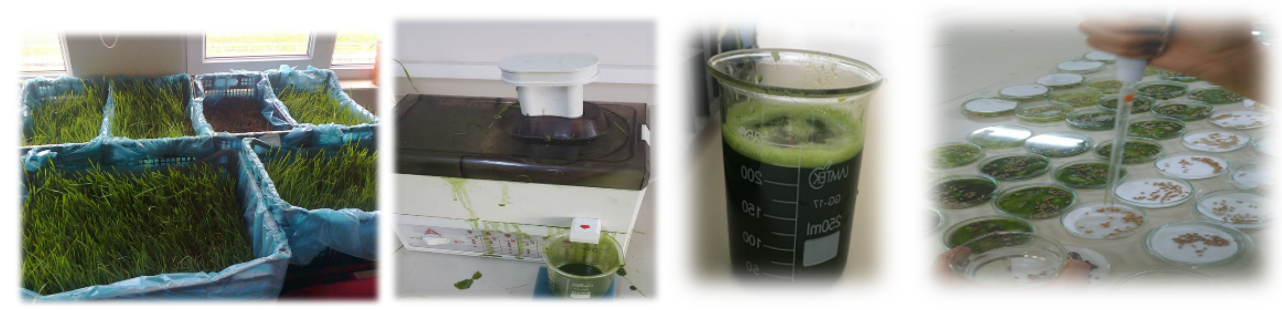

Figure 1. Oat grass cultivated, grass juice obtained, oat grass juice and centrifuged oat grass juice applications

\section{Şekil 1. Yulaf çimi yetiştirilmesi, çim suyu çıkarılması, yulaf çim suyu ve santrifüj edilmiş yulaf çim suyu uygulamalart}

Farklı türlere ait tohumlar $9 \mathrm{~cm}$ çaplı petri kaplarında, Whatman (No:3) filtre kâğıtları üzerinde çimlendirilmiştir. Petri kaplarına, arpa, buğday, yulaf, fasulye ve ayçiçeğinden 25 adet, mercimek, şeker pancarı, İtalyan çimi, kırmızı üçgül, yonca, horoz ibiği ve yabani hardaldan 50 adet tohum konulmuştur. ISTA (1996)'da belirtilen esaslara göre çimlendirme petri kaplarında $22-24{ }^{\circ} \mathrm{C}$ sıcaklıkta inkübatörde yapılmıştır. Tohumlar çimlenme ortamına konulduktan sonra her gün kontrol edilerek çimlenenlerin sayıları belirlenmiştir.

Çim suyu, elde etmek amacıyla yulaf tohumları $30 \times 50 \mathrm{~cm}$ kasalara sık bir şekilde ekilmiştir. 14 gün sonunda biçime hazır hale gelen yulaflar makas ile biçilerek katı meyve suyu sıkacağında geçirilerek tamamen parçalanması sağlanmış ve çim suyu elde edilmiştir (Rexhepi ve Reneta, 2015b; Şekil 1). Daha sonra santrifüj edilmiş çim suyu elde etmek için 5 dakika süreyle 5000 rpm'de santrifüj edilmiştir. Süpernatant kısmı alınarak, $\% 100, \% 75, \% 50$ ve $\% 25$ oranlarında saf su ile seyreltilerek tohumlara direk uygulanmıştır. Her bir petri için, küçük çaplı tohumlara (mercimek, şeker pancarı, İtalyan çimi, kırmızı üçgül, yonca, horoz ibiği ve yabani hardal) $10 \mathrm{ml}$, büyük çaplı (arpa, buğday, yulaf, fasulye ve ayçiçeği) tohumlara $15 \mathrm{ml}$ olacak şekilde santrifüj edilmemiş yulaf çim suyu ve santrifüj edilmiş YÇS dozları (\%25, \%50, \%75 ve \%100) verilmiştir. Her türe ait kontrol grubundaki tohumlara da aynı miktarda ( $10 \mathrm{ml}$ ve $15 \mathrm{ml} \mathrm{saf} \mathrm{su)} \mathrm{uygulanmıştır.} \mathrm{ISTA} \mathrm{kurallarına} \mathrm{göre} \mathrm{her} \mathrm{bir} \mathrm{tür} \mathrm{için} \mathrm{değerlendirmelerde}$ farklı süreler (arpa:4-7 gün; buğday:4-8 gün; yulaf: 5-10 gün; fasulye:5-9 gün; mercimek:5-10 gün, şeker pancarı:4-14 gün; ayçiçeği:4-10 gün; İtalyan çimi:5-14 gün; kırmızı üçgül:4- 7 gün; yonca: 5-10 gün; horoz ibiği:414 gün ve yabani hardal: 3-7 gün) dikkate alınmıştır (ISTA, 1996). Denemede incelenen özellikler aşağıda belirtilmiştir.

Çimlenme oranı (\%): (Çimlenen tohumların sayısı/ çimlenme ortamına konulan tohum sayısı) x 100 formülüne göre çimlenme oranları hesaplanmıştır. Çimlenme indeksi aşağıda belirtilen eşitlik 1 den yararlanılarak hesaplanmıştır. 
Karaman \& Türkay \& Akgün Yulaf Çim Suyunun Bazı Yabancı Ot ve Kültür Bitkisi Tohumlarının Çimlenme ile Fide Özellikleri Üzerine Etkileri

Burada G1...Gn sırasıyla 1. ve Gn (çimlenmeye son verildiği gün) günlere ait çimlenme yüzdelerini ifade etmektedir (Esechie, 1994). Kök ve Sürgün Uzunluğu (cm): Tohumlar ISTA kurallarına göre çimlenme sürelerinin sonunda fidelerin kök ve sürgünleri birleşme yerlerinden jiletle kesilerek uzunlukları milimetrik bir cetvel yardımı ile ölçülmüştür (Bozcuk, 1978). Bir petrideki kök ve sürgün uzunlukları toplamının, fide sayısına bölünmesiyle ortalama kök/sürgün uzunluğu cm/bitki olarak hesaplanmıştır. Yaş ve Kuru Ağırlık (g): Seçilen 10 fidenin yaş ağırlıkları 0.01 duyarlı hassas terazide tartılarak g cinsinden saptanmıştır. Yaş ağırlıkları belirlenen fideler $65^{\circ} \mathrm{C}$ 'de bir gün etüvde kurutulduktan sonra hassas terazide tartılarak g olarak kuru ağırlıkları belirlenmiştir.

Denemede incelenen özelliklere ilişkin elde edilen verilerle, her tür için tesadüf parselleri deneme desenine göre MINITAB istatistik paket programı ile varyans analizi yapılmış ve farklılık gruplandırmaları 0.05 düzeyinde Tukey testi göre yapılmıştır.

\section{Araştırma Sonuçları ve Tartışma}

Çalışmada YÇS ve santrifüj edilmiş YÇS dozlarının uygulanması sonucunda, tüm türler üzerine uygulamaların kontrole göre olumsuz etkisi olduğu ve hatta bazı türlerde (yabani hardal, horoz ibiği, şeker pancarı, İtalyan çimi ve kırmızı üçgül) çimlenme görülmediği belirlenmiştir. Kontrol grupta çimlenme oranı; yabani hardalda \%44, horoz ibiğinde \%70.7, şeker pancarında \%31.3, İtalyan çiminde \%83.3 ve kırmızı üçgülde \% 45.3 olarak tespit edilmiştir. Yulaf çim suyu uygulamalarında çimlenmeyen türler deneme dışı bırakılmıştır. Araştırmada fasulye, mercimek, arpa, buğday, yulaf, ayçiçeği ve yonca türlerinin çimlenme oranı, çimlenme indeksi, fide ve kök uzunluğu ile yaş ve kuru ağırlık özellikleri incelenmiş ve her türe çalışmadaki deneme planına uygun varyans analizi yapılmış ve uygulamaların etkisi istatistiki olarak önemli bulunmuştur.

\section{1. Çimlenme Oranı ve Çimlenme İndeksi}

Çalışmada fasulye türünün çimlenme oranı değerleri incelendiğinde, en yüksek değerler kontrol uygulamasında (\%90) belirlenmiş ve bu değeri santrifüj edilmiş \%25 YÇS uygulaması (\%68.6) takip etmiştir (Tablo 1). Santrifüj edilmiş YÇS dozlarının artması ile çimlenme oranı değerleri de azalmıştır. Fasulyede en düşük çimlenme oranı YÇS uygulamasında (\%33.6) tespit edilmiştir. Mercimek, arpa ve yulaf türlerinde çimlenme sadece kontrol ve santrifüj edilmiş \%25 YÇS uygulamasında görülmüş, diğer uygulamalarda çimlenme görülmemiştir. Buğday, ayçiçeği ve yonca türlerinde, en yüksek çimlenme oranı değerleri (sırasıyla \% $77.9 ; \% 90.0$ ve \%68.2) kontrol uygulamalarında belirlenmiş, santrifüj edilmiş YÇS uygulamaları ile çimlenme oranı da azalmıştır. Buğday türünde YÇS ve santrifüj edilmiş \%50, \%75 ve \%100 YÇS uygulamalarında çimlenme olmamıştır. Ayçiçeği ve yonca türlerinde en düşük çimlenme oranı YÇS (sırasıyla \%11.5 ve \%37.4) ve santrifüj edilmiş \%100 YÇS (sırasıyla \%14.0 ve \%36.2) uygulamalarında belirlenmiştir. Ayrıca yoncada en düşük çimlenme oranı \%100 SYÇS'dan belirlenmesine rağmen, YÇS, \%75 SYÇS ve \%50 SYÇS ile arasındaki fark önemsiz olarak bulunmuştur.

Araştırmada incelenen özelliklerden çimlenme indeksi, tohumların kısa sürede yüksek çimlenme yüzdesi oluşturan uygulamayı belirleyebilmek amacıyla kullanılmaktadır (Akgün ve ark., 2018a). Araştırmada YÇS uygulamalarının çimlenme indeksi üzerine etkileri incelendiğinde, kullanılan türlerin hepsinde en yüksek çimlenme indeksi kontrol grubunda belirlenmiş ve bu grubu santrifüj edilmiş \%25 YÇS uygulaması takip etmiştir. Santrifüj edilmiş YÇS dozlarının artmasına bağlı olarak çimlenme indeksinde azalmalar saptanmıştır. Mercimek, arpa ve yulaf türlerinde yulaf çim suyu, \%50, \%75 ve \%100 santrifüj edilmiş YÇS dozlarında çimlenme olmamasından dolayı çimlenme indeksi hesaplanamamıştır (Tablo 1).

Bitkilerde bulunan sekonder metabolitlerden oluşan allelokimyasallar tohumların çimlenmesi ve fide büyümesini engelleyebilmekte veya teşvik edebilmektedir (Zeng ve ark., 2008). Yapılan bazı çalışmalarda bitkilerdeki allelokimyasalların, farklı bitki aksamlarından çıkan uçucu maddeler olduğunu (Bradow ve Connick, 1998), bazı maddelerin bitki köklerinden salgılandığını (Qasem ve Hill, 1989) ve bazılarının ise de bitkilerin toprak üstü kısımlarından su ile çözünüp toprağa karıştığını (Qasem, 1994) bildirilmiştir (Özbay, 2018). Gürsoy ve ark. (2013), bitki aksamlarının (kök, yaprak, sap vb.) veya bu aksamlarına parçalanıp ayrışması ile salgılanan kimyasalların farklı konsantrasyonlarının üretim kayıplarına neden olduğunu ifade etmişlerdir. Yulafta da bulanan allelopatik maddeler nedeniyle, yulaf çim suyu ve santrifüj edilmiş yulaf çim suyu konsantrasyonları kültür ve yabancı ot tohumlarının çimlenme özellikleri (çimlenme indeksi ve oranı) üzerine allelopatik (engelleyici) etkide 
bulunmuştur. Çimlenme oranı, tohumun ekim formunu karakterize etmede kullanılan önemli bir faktör olup (Delchev, 2017), tohumun canlılığı hakkında da bilgi vermektedir. Qasem ve Issa (2003) kabak sürgünlerinden elde ettiği özsuyun horozibiği ve sirken yabancı otları tohumlarına uygulamış ve bu uygulama ile çimlenmesinin engellediğini tespit etmişlerdir. Özbay (2018), bitki ekstratlarının biberin çimlenme ve fide gelişimi üzerine etkilerini belirlemek amacıyla yaptığı çalışmada, bitki ekstratlarının engelleme etkisinin ve oranının türlere ve dozlara bağlı olarak değiştiğini ifade etmiştir. Stratu ve ark. (2012), selam otu ve kereviz bitkisi yapraklarından elde ettikleri ekstraktın mercimek tohumlarının çimlenme ve fide gelişimi üzerine olumsuz etkide bulunduğunu ve çimlenmeyi geciktirip engellediğini hatta kök gelişimini engellediğini bildirmişlerdir. Bir diğer araştırmada, Chromolaena odorata bitkisi yapraklarından ve köklerinden elde edilen ekstraktlarının (\% 0.1 ve 10) tohum çimlenmesi ve fide gelişimi üzerine olumsuz etkide bulunduğu saptanmıştır (Hu ve Zhang, 2013). Pek çok araştırmacının yaptığı çalışmalar, elde ettiğimiz sonuçları destekler niteliktedir.

Tablo 1. Farklı türlerin çimlenme oranı (\%) ve çimlenme indeksine ait değerler Table 1. Germination ratio (\%) and germination index values of different species

\begin{tabular}{|c|c|c|c|c|c|c|c|c|}
\hline \multirow{9}{*}{ 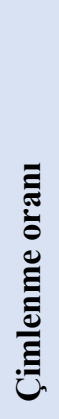 } & Uygulamalar & Fasulye & Mercimek & Arpa & Buğday & Yulaf & Ayçiçeği & Yonca \\
\hline & Kontrol & $90.00 \mathrm{a}^{*}$ & $76.78 \mathrm{a}$ & $71.61 \mathrm{a}$ & $77.94 \mathrm{a}$ & $55.58 \mathrm{a}$ & $90.00 \mathrm{a}$ & $68.20 \mathrm{a}$ \\
\hline & Yulaf Çim Suyu & $33.59 \mathrm{e}$ & - & - & - & - & $11.54 \mathrm{e}$ & $37.42 \mathrm{c}$ \\
\hline & $\% 25$ SYÇS & $68.63 \mathrm{~b}$ & $47.72 \mathrm{~b}$ & $20.23 \mathrm{~b}$ & $44.62 \mathrm{~b}$ & $27.87 \mathrm{~b}$ & $29.28 \mathrm{~b}$ & $52.00 \mathrm{~b}$ \\
\hline & \%50 SYÇS & $55.05 \mathrm{c}$ & - & - & $20.08 \mathrm{c}$ & - & $20.26 \mathrm{c}$ & $46.49 \mathrm{bc}$ \\
\hline & $\% 75$ SYÇS & $46.73 \mathrm{~d}$ & - & - & - & - & $18.22 \mathrm{~cd}$ & $42.12 b c$ \\
\hline & $\% 100$ SYÇS & $48.46 \mathrm{~cd}$ & - & - & - & - & $13.98 \mathrm{de}$ & $36.16 \mathrm{c}$ \\
\hline & Tukey & 7.26 & 0.73 & 0.61 & 0.73 & 0.33 & 0.56 & 1.03 \\
\hline & $C v(\%)$ & 5.44 & 1.51 & 1.68 & 1.36 & 1.11 & 0.78 & 0.95 \\
\hline \multirow{8}{*}{ 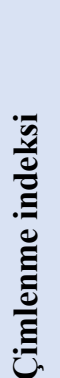 } & Kontrol & $6.62 \mathrm{a}$ & $16.04 \mathrm{a}$ & $13.96 \mathrm{a}$ & $6.93 \mathrm{a}$ & $6.88 \mathrm{a}$ & $7.31 \mathrm{a}$ & $10.28 \mathrm{a}$ \\
\hline & Yulaf Çim Suyu & $1.08 \mathrm{e}$ & - & - & - & - & $0.37 \mathrm{~d}$ & $2.93 \mathrm{f}$ \\
\hline & $\% 25$ SYÇS & $3.87 \mathrm{~b}$ & $7.25 \mathrm{~b}$ & $1.10 \mathrm{~b}$ & $3.80 \mathrm{~b}$ & $1.60 \mathrm{~b}$ & $1.35 \mathrm{~b}$ & $6.05 \mathrm{~b}$ \\
\hline & $\% 50 S Y C ̧ S$ & $3.19 \mathrm{c}$ & - & - & $0.71 \mathrm{c}$ & - & $0.82 \mathrm{c}$ & $4.76 \mathrm{c}$ \\
\hline & $\% 75 S Y C ̧ S$ & $2.04 \mathrm{~d}$ & - & - & - & - & $0.64 \mathrm{c}$ & $3.87 \mathrm{~d}$ \\
\hline & $\% 100$ SYÇS & $1.44 \mathrm{e}$ & - & - & - & - & $0.19 \mathrm{~d}$ & $3.23 \mathrm{e}$ \\
\hline & Tukey & 0.47 & 1.26 & 0.10 & 0.10 & 0.08 & 0.24 & 0.30 \\
\hline & $C v(\%)$ & 6.74 & 4.39 & 1.61 & 2.22 & 2.36 & 5.74 & 2.50 \\
\hline
\end{tabular}

SYÇS: Santrifüj edilmiş yulaf çim suyu; *Aynı sütunda farklı harflerle gösterilen ortalamalar arasındaki fark önemlidir $(\mathrm{P}<0.05)$.

\subsection{Sürgün ve Kök Uzunluğu}

Araştırma sonuçlarına göre Tablo 2 incelendiğinde, santrifüj edilmiş YÇS dozlarının artmasına bağlı olarak bitki türlerinin sürgün ve kök uzunlukları azalmıştır. Bitki türlerinde en yüksek sürgün ve kök uzunluğu kontrol grubunda belirlenmiş olup, bu uygulamayı \%25 santrifüj edilmiş YÇS uygulaması takip etmiştir. Mercimekte kontrol ile \%25 santrifüj edilmiş YÇS konsantrasyonlarına ait kök uzunluğu değerleri arasında istatistiki olarak fark bulunmamıştır. Fasulyede en küçük sürgün ve kök uzunluğu YÇS uygulamasında (çimlenme olmuş ancak sürgün ve kök uzunluğu ölçülemeyecek şekildedir) belirlenmiştir (Tablo 2). Mercimek, arpa, buğday ve yulafin kök uzunlukları kontrolden sonra \%25 santrifüj edilmiş YÇS konsantrasyonunda (sırasıyla $1.37 \mathrm{~cm}, 5.72 \mathrm{~cm}, 2.14$ $\mathrm{cm}$ ve $6.50 \mathrm{~cm}$ ) belirlenmiştir. Tüm bitki türlerinde YÇS uygulaması, mercimek, arpa ve yulafta $\% 50, \% 75$ ve \%100 santrifüj edilmiş YÇS uygulaması, buğday, ayçiçeği ve yoncada tüm santrifüj edilmiş YÇS dozları uygulamasında, çimlenme olmamasından veya çimlenme olup fidelerin ölçüm yapılamayacak kadar küçük olması sebebiyle sürgün ve kök uzunluğu belirlenememiş olup, buna paralel olarak yaş ve kuru ağırlıkları tespit edilememiştir.

Bitkilerin vejetasyon süreci boyunca çimlenme dönemi en kritik ve en hassas dönemlerden birisidir (Ergin ve Kaya, 2020). Bu kritik dönemde tohumlara yüksek dozda allelokimyasal uygulandığında çimlenme oranı, sürgün ve kök uzunluğu ile yaş ve kuru ağırlıklarında azalma belirlenirken; bazı düşük dozlarda ise, fide gelişimini teşvik ettiği saptanmıştır (Maqbool, 2010; Far ve Bagherzadeh 2018). Ayrıca, bitkilerin çeşitli nedenlerden dolayı maruz 
Karaman \& Türkay \& Akgün Yulaf Çim Suyunun Bazı Yabancı Ot ve Kültür Bitkisi Tohumlarının Çimlenme ile Fide Özellikleri Üzerine Etkileri kaldığı stres faktörleri nedeniyle mitotik indeks ve hücre bölünmesinde de azalmalara ve kromozom anormalliklerine neden olduğu bildirilmektedir (Avalbaev ve ark., 2003; Tabur ve Demir, 2008). SánchezMoreiras ve ark. (2004), yulaf bitki aksamlarından hazırladıkları solüsyon ile yulafın çimlenme ve fide gelişimi üzerine etkilerini araştırmışlardır. Çalışmada yulaftan hazırlanan bu solüsyonun yulaf tohumlarının çimlenme, sürgün ve kök uzunluğu özellikleri üzerine engelleyici (allelopatik) etki gösterdiğini saptamışlardır. Özdemir (2007), turp türleri ve şalgam bitkilerinden elde ettiği bitki özütleri dozlarını horozibiği, kısır yabani yulaf, semizotu, yabani hardal üzerine uygulamış ve artan dozlara paralel olarak çimlenme ile sürgün ve kök uzunluklarında önemli ölçüde azalma belirlemiştir. Lam ve ark. (2012), buğday saplarının ayçiçeği tohumları üzerine çimlenme ve fide gelişimine etkilerini belirledikleri çalışmada, buğday saplarının ayçiçeği, soya fide gelişiminde allelopatik etkisi olduğunu tespit etmişlerdir. Ergin ve Kaya (2020), yulaf çeşitlerinde artan ekstrakt dozlarının fide gelişimini önemli seviyede engellediğini bildirmişlerdir. Yapılan bu çalışmaların sonuçları elde ettiğimiz sonuçlara benzerlik göstermektedir.

Tablo 2. Farklı türlerin sürgün ve kök uzunluğuna (cm) ait değerler

Table 2. Shoot and root length (cm)values of different species

\begin{tabular}{|c|c|c|c|c|c|c|c|c|}
\hline \multirow{9}{*}{ 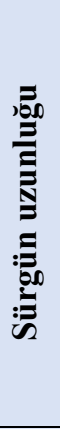 } & Uygulamalar & Fasulye & Mercimek & Arpa & Buğday & Yulaf & Ayçiçeği & Yonca \\
\hline & Kontrol & $1.62 \mathrm{a}^{*}$ & $6.15 \mathrm{a}$ & $6.90 \mathrm{a}$ & 9.14 & $14.01 \mathrm{a}$ & 7.77 & 5.76 \\
\hline & Yulaf Çim Suyu & - & - & - & - & - & - & - \\
\hline & $\% 25$ SYÇS & $1.44 \mathrm{~b}$ & $5.43 \mathrm{~b}$ & $2.87 \mathrm{~b}$ & - & $4.02 \mathrm{~b}$ & - & - \\
\hline & $\% 50$ SYÇS & $0.80 \mathrm{c}$ & - & - & - & - & - & - \\
\hline & $\% 75$ SYÇS & $0.44 \mathrm{~d}$ & - & - & - & - & - & - \\
\hline & $\% 100$ SYÇS & $0.36 \mathrm{e}$ & - & - & - & - & - & - \\
\hline & Tukey & 0.05 & 0.10 & 0.25 & 0.10 & 0.07 & 0.03 & 0.05 \\
\hline & $C v(\%)$ & 2.74 & 2.21 & 6.71 & 2.81 & 1.17 & 1.18 & 1.97 \\
\hline \multirow{8}{*}{ 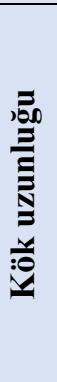 } & Kontrol & $15.67 \mathrm{a}$ & 1.37 & $13.69 \mathrm{a}$ & $12.15 \mathrm{a}$ & $19.33 \mathrm{a}$ & 7.70 & 1.79 \\
\hline & Yulaf Çim Suyu & $1.54 \mathrm{f}$ & - & - & - & - & - & - \\
\hline & $\% 25$ SYÇS & $12.58 \mathrm{~b}$ & 1.37 & $5.72 \mathrm{~b}$ & $2.14 \mathrm{~b}$ & $6.50 \mathrm{~b}$ & - & - \\
\hline & $\% 50$ SYÇS & $8.17 \mathrm{c}$ & - & - & - & - & - & - \\
\hline & $\% 75$ SYÇS & $4.57 \mathrm{~d}$ & - & - & - & - & - & - \\
\hline & $\% 100$ SYÇS & $2.26 \mathrm{e}$ & - & - & - & - & - & - \\
\hline & Tukey & 0.31 & 0.11 & 0.19 & 0.46 & 0.88 & 0.08 & 0.02 \\
\hline & $C v(\%)$ & 1.80 & 10.01 & 6.71 & 0.8 & 8.87 & 2.75 & 3.44 \\
\hline
\end{tabular}

SYÇS: Santrifüj edilmiş yulaf çim suyu; * Aynı sütunda farklı harflerle gösterilen ortalamalar arasındaki fark önemlidir $(\mathrm{P}<0.05)$.

\subsection{Fide Yaş ve Kuru Ăğırlık}

Çalışmada farklı bitki türlerine ait yaş ağırlık değerleri, en yüksek kontrol grubunda tespit edilmiş ve bu uygulamayı \%25 santrifüj edilmiş YÇS uygulaması takip etmiştir. Fide yaş ağırlığı yönünden fasulye ve mercimeğin \%25 santrifüj edilmiş YÇS dozu ile kontrol grubu aynı istatistik grupta yer almıştır. Fasulyede en küçük yaş ağırlık değeri, \%100 santrifüj edilmiş YÇS konsantrasyonunda belirlenirken, YÇS ve \%75 santrifüj edilmiş, YÇS konsantrasyonu ile aralarında istatistiki olarak fark bulunamamıştır (Tablo 3). Kuru ağırlık yönünden fasulyede YÇS uygulamaları incelendiğinde ise, \%25, \%50 ve \%75 santrifüj edilmiş YÇS dozları ve yulaf çim suyu (YÇS) en yüksek değerlere sahip olmuş ve bu dört uygulama arasında istatistiki bir fark belirlenememiştir. Mercimek, arpa, buğday yulaf türlerinin kuru ağırlıkları incelendiğinde en yüksek değerler kontrol grubunda tespit edilmiş olup, bu grubu \%25 santrifüj edilmiş YÇS dozu takip etmiştir. Ayçiçeği ve yonca türlerinde ise, YÇS uygulamaları ile fide özellikleri ölçülemeyecek boyda olduğu için yaş ve kuru ağırlık özellikleri belirlenememiştir (Tablo 3).

Allelokimyasalların etkileri türden türe değişebilmekte olup bir türde olumsuz, bir diğerinde ise olumlu yönde etki yapabilmektedir. Bu durum allelokimyasalların türüne, konsantrasyonuna ve uygulama süresine göre değişmektedir. Fakat, allelokimyasallar bitkilerin gelişimine genellikle olumsuz olarak etki etmektedir. Allelokimyasallar bitkiler üzerine; fotosentezi azaltarak, büyüme ve solunum olaylarında aksaklılara neden olarak, 
çimlenmeyi engelleyerek, hücre bölünmesi üzerine etki ederek, bitkilerin besin maddelerini absorbe etmesini engelleyerek, kloroz, deformasyon, yaprak dökümü, kurumaya ve ölüm gibi olaylara neden olarak etki etmektedirler (Yurttaş Kılınç, 2015). Özbay (2018), farklı bitki türlerinden elde ettiği özütleri biber tohumlarına uygulamış ve bunun sonucunda, özüt uygulamaları kontrol ile kıyaslandığında, fide yaş ve kuru ağırlığı ile kök yaş ve kuru ağırlığının önemli ölçüde azaldığını ve buna bağlı olarak fide gelişimini engellediğini saptamıştır. Araştırıcı sonuç olarak engelleme etkisi ve oranının özüt elde edilen bitkilere ve özüt dozuna bağlı olarak değiştiğini bildirmiş̧tir. Far ve Bagherzadeh (2018), anason fidelerini toprak yüzeyinden kesip, kuruttuktan sonra toz haline getirip solüsyon hazırlamışlar ve farklı dozlarını arpa, buğday, mısır ve ayçiçeği tohumları üzerine uygulamışlardır. Çalışma sonunda buğdayda $\% 0$ ve \%25 anason ekstrakt dozlarının fide ve kök uzunluğu üzerine olumlu, artan dozlarının olumsuz etkide bulunduğunu, bu durumun aksine diğer türlerde ise anason ekstrakt uygulamaları ile fide ve kök uzunluklarında azalma meydana geldiğini ifade etmişlerdir. Fide gelişimine paralel olarak fide ve kuru ağırlık özelliklerinde de buğday haricinde anason ekstrakt uygulamaları ile azalma belirlediklerini ifade etmişlerdir.

Tablo 3. Farklı türlerin fide yaş ve kuru ağırlı̆̆ına (g) ait dĕgerler

Table 3. Seedling wet and dry weights $(g)$ of different species

\begin{tabular}{|c|c|c|c|c|c|c|c|c|}
\hline \multirow{9}{*}{ 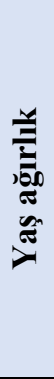 } & Uygulamalar & Fasulye & Mercimek & Arpa & Buğday & Yulaf & Ayçiçeği & Yonca \\
\hline & Kontrol & $13.60 \mathrm{a}^{*}$ & 0.60 & $2.20 \mathrm{a}$ & $1.83 \mathrm{a}$ & $1.45 \mathrm{a}$ & 3.98 & 0.64 \\
\hline & Yulaf Çim Suyu & $11.39 \mathrm{c}$ & - & - & - & - & - & - \\
\hline & $\% 25$ SYÇS & $13.16 \mathrm{ab}$ & 0.60 & $0.45 \mathrm{~b}$ & $0.95 \mathrm{~b}$ & $0.61 \mathrm{~b}$ & - & - \\
\hline & $\% 50$ SYÇS & $12.95 \mathrm{~b}$ & - & - & - & - & - & - \\
\hline & $\% 75$ SYÇS & $11.21 \mathrm{c}$ & - & - & - & - & - & - \\
\hline & $\% 100$ SYÇS & $11.03 \mathrm{c}$ & - & - & - & - & - & - \\
\hline & Tukey & 0.51 & 0.02 & 0.05 & 0.06 & 0.07 & 0.07 & 0.02 \\
\hline & $C v(\%)$ & 1.82 & 5.09 & 5.03 & 5.37 & 8.62 & 4.25 & 9.01 \\
\hline \multirow{8}{*}{ 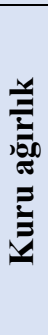 } & Kontrol & $2.81 \mathrm{~b}$ & $0.08 \mathrm{a}$ & $0.29 \mathrm{a}$ & $0.82 \mathrm{a}$ & $0.13 \mathrm{a}$ & 0.5 & 0.10 \\
\hline & Yulaf Çim Suyu & $3.12 \mathrm{a}$ & - & - & - & - & - & - \\
\hline & $\% 25 S Y C ̧ S$ & $3.06 \mathrm{a}$ & $0.07 \mathrm{~b}$ & $0.24 \mathrm{~b}$ & $0.35 \mathrm{~b}$ & $0.07 \mathrm{~b}$ & - & - \\
\hline & $\% 50$ SYÇS & $3.18 \mathrm{a}$ & - & - & - & - & - & - \\
\hline & \%75 SYÇS & $3.12 \mathrm{a}$ & - & - & - & - & - & - \\
\hline & $\% 100$ SYÇS & $2.83 \mathrm{~b}$ & - & - & - & - & - & - \\
\hline & Tukey & 0.15 & 0.00 & 0.01 & 0.05 & 0.00 & 0.01 & 0.01 \\
\hline & $C v(\%)$ & 2.13 & 0.49 & 4.60 & 10.72 & 1.28 & 0.40 & 14.88 \\
\hline
\end{tabular}

SYÇS: Santrifüj edilmiş yulaf çim suyu *Aynı sütunda farklı harflerle gösterilen ortalamalar arasındaki fark önemlidir $(\mathrm{P}<0.05)$.

\section{Sonuç}

Çalışmada yulaf çim suyunun kültür ve yabancı otların çimlenme ve fide gelişim üzerine olumsuz etkisi belirlenmiştir. Bazı türlerde (yabani hardal, horozibiği, şeker pancarı, İtalyan çimi ve kırmızı üçgül) kontrol grupta çimlenme meydana gelmiş olmasına rağmen, yulaf çim suyu çimlenmeyi tamamen engellemiştir. Santrifüj edilmiş yulaf çim suyu düşük dozda uygulandığında ise bu olumsuz etki türlere göre değişmekle birlikte kısmen azalmıştır.

Yulaf çim suyu mineral madde, vitaminler, protein ve antioksidan içerikleri yönünden zengin olmasına rağmen, tohum çimlenmesi ve fide gelişiminde doğrudan bioaktivatör olarak kullanılamayacağı belirlenmiştir. Çim sularının içerdiği birçok allelopatik etkiye sahip maddeler tohum çimlenmesini engellemektedir. Özellikle yulaf bitkisinde bulunan saponin (avenacins), hidroxamik asit, skopoletin, L-triptofan gibi maddelerin tohum çimlenmesini engellediği düşünülmektedir. Bu nedenle sürdürülebilir tarım uygulamaları içerisinde yulaftan elde edilecek çim sularının, kültür bitkilerine olumsuz etkisi belirlendiğinden, doğrudan herbisit olarak kullanılabilme potansiyelinin de olmadığı söylenebilir. 


\section{Kaynakça}

Akgün, İ., Ayata, R., Karaman, R., Karaca, G. (2018). Effect of wheatgrass (Triticum aestivum L.) juice on seedling growth and Rhizoctonia solani in corn. Scientific Papers Series A. Agronomy 61(1): 149-154

Akgün, İ., Ayata, R., Karaman, R. (2018). Buğday (Triticum aestivum L.) Çim Suyunun Tohum Çimlenmesi Üzerine Etkisi. Akademia Mühendislik ve Fen Bilimleri Dergisi 1 (4): 19-24

Ashish, S., Shilpa, K., Singh, R. R., Sanjay, K., Rajendran, N. (2012). Wheatgrass: An alternative household nutritional food security. International Research Journal of Pharmacy 3(7): 246-250

Avalbaev, A.M., Bezrukova, M.V., Kildibekova, A.R., Fatkhutdinova, R.A., Shakirova, F.M. (2003). Wheat germagglutinin restores cell division and growth of wheat seedlings under salinity. Bulgarian Journal of Plant Physiology 257- 263

Berry, N.M., Robinson, M.J., Bryan, J., Buckley, J.D., Murphy, KJ, Howe, P.R. (2011). Acute effects of an Avena sativa herb extract on responses to the stroop color-word test. Journal of Alternative and Complementary Medicine 17(7):635-637

Bozcuk, S. (1978). Domates (Leycopersicum esculentum Mill.), arpa (Hordeum vulgare L.) ve pamuk (Gossypium hirsitum L.) bitkilerinin büyüme ve gelişmelerinde tuz kinetin etkileşimi üzerine araştırmalar. (Doçentlik tezi) Hacettepe Üniversitesi Fen Fakültesi Botanik Bölümü, Ankara

Bradow, J.M., Connick, W.J. (1998). Seed germination inhibition by volatile alcohols and other compounds associated with Amaranthus palmeri residues. Journal of Chemical Ecology 14: 1633-1648

Delchev, G. (2017). Impact of Some Mixtures between Foliar Fertilizers and Combined Herbicides on the Sowing Properties of the Durum Wheat Sowing-Seeds. Journal of Tekirdag Agricultural Faculty 2(SP):20-24

Demirci M. (2009) Beslenme. Namık Kemal Üniversitesi Ziraat Fakültesi Gıda Mühendisliği Bölümü, Tekirdağ

Ergin, N., Kaya, M. D. (2020). Bazı yağ bitkileri tohumlarının çimlenme ve fide gelişimi üzerine iki yulaf çeşidinin allelopatik etkileri. Iğdır Üniversitesi Fen Bilimleri Enstitüsü Dergisi 10(2): 1419-1428.

Ergün, T. (2011). Bazı tahıl cinslerinin çim suyu verimi ve kalitesinin belirlenmesi. (Yüksek Lisans Tezi) Selçuk Üniversitesi Fen Bilimleri Enstitüsü, Konya

Esechie, H.A. (1994). Interaction of salinity and temperature on the germination of sorghum. Journal Agronomy and Crop Science 172: 194199.

Far, M.H., Bagherzadeh, A. (2018). Assessing allelopathic index for estimating allelopathic potential of Ajowan extracts. Journal of Crop Science and Biotechnolog 21(2): 165-172.

Finney, P.L. (1982). Effect of Germination on Cereal and Legume Nutrient Changes and Food or Feed Value. Phytochemistry, New York and London

Ghiyasi, M., Özdemir, F. A., Amirnia, R., Tajbakhsh, M., Rahimi, A. (2016). Kolza (Brassica napus L.) tohumlarında çimlenme ve anormal çim oranı üzerine, Chenopodium album L.'un allelopatik etkisi. Bitlis Eren Üniversitesi Fen Bilimleri Dergisi 5(2): 225-228

Gürsoy, M., Balkan, A., Ulukan, H. (2013). Bitkisel üretimde allelopati. Uludağ Üniversitesi Ziraat Fakültesi Dergisi 27(2): 115-122

Hu, G., Zhang, Z. (2013). Allelopathic effects of chromolaena odorata on native and non-native invasive herbs. Journal of Food, Agriculture \& Environment 11(1): 878-882

ISTA, (1996). The Rules: International Rules for Seed Testing: ISTA, Zürih, İsviçre

Karaman, R., Erbaş, S., Baydar, H., Kaya M. (2014). Allelopathic effect of lavandin (Lavandula x intermedia Emeric ex Loisel. var. Super A) oil on germination and seedling development of some weed and field crops. Harran Tarım ve Gida Bilimleri Dergisi 18(4): 35-41

Karaşahin, M. (2015). Topraksız ortamda yetiştirilen bazı tahılların çim suyu verim ve besin değerleri. Iğdır Üniversitesi Fen Bilimleri Enstitüsü Dergisi 5(4): 57-64

Kennedy, D. O., Jackson, P. A., Forster, J., Khan, J., Grothe, T., Perrinjaquet-Moccetti, T., Haskell-Ramsay, C. F. (2017). Acute effects of a wild green-oat (Avena sativa) extract on cognitive function in middle-aged adults. Nutritional neuroscience 20(2): 135-151

Kuca, D., Yağdı, K. (2021). Bazı Ayçiçeği ve Mısır Çeşitlerinde Tohuma Uygulanan İlaçların Tohumluğun Çimlenme Değeri Üzerine Etkileri. Journal of Tekirdag Agricultural Faculty 18(1):45-57

Lam, Y., Sze, C.W., Tong. Y., Tang, S.C.W., Ho, J.C.M., Liao, Q.X., Zhang, Y. (2012). Research on the allelopathic potential of wheat. Agricultural Sciences 3(8): 979-985

Maqbool, N. (2010). Exploring the role of sorgaab in improving water stress tolerance in maize at germination and vegetative growth stages. (Doctoral dissertation) Department of Botany University of Agriculture, Faisalabad, Pakistan

Oudhia, P. (2000). Allelopathic effects of Parthenium hysterophorus and Ageratum conyzoides on wheat var.Sujata. Crop Research 20(3): $563-566$ 
Oueslati, O. (2003). Allelopathy in two durum wheat (Triticum durum L.) varieties. Agriculture, Ecosystems and Environ 96: 161-163

Osbourn, A. E. (2003). Saponins in cereals. Phytochemistry, 62(1): 1-4

Özbay, N. (2018). Bazı tıbbi bitki ve yabancı ot ekstraktlarının biberin çimlenme ve fide gelişimi üzerine etkisi. Türk Tarım ve Doğa Bilimleri Dergisi 5(1): 81-85

Özdemir, Ş. (2007). Brassıcaceae familyasından bazı bitkilere ait yabancı otlarla mücadelede biyo-herbisit olarak kullanılabilme olanaklarının araştırılması. (Yüksek Lisans Tezi) Mustafa Kemal Üniversitesi Fen Bilimleri Enstitüsü, Antakya

Qasem, J.R. (1994). Allelopathic effect of white top (Lepidium draba) on wheat and barley. Allelopathy Journal 1: 29-40

Qasem, J.R., Hill, T.A. (1989). Possible role of allelopathy in the competition between tomato, Senecio vulgaris L. and Chenopodium album L. Weed Research 29: 349-356.

Qasem, L.R., Issa, N.N. (2003) Allelopathic effects of squash (Cucurbita pepo L. Cv. Scarlette) on ceratain common weed species in Jordan. Deparment of Plant Protection Faculty of Agriculture, University of Jordan

Reigosa, M.J., Pedrol, N., Sánchez-Moreiras, A.M., González, L. (2002). Stress and Allelopathy. Allelopathy from Molecules to Ecosystems, 231-256

Rexhepi, A. H., Renata, K. (2015a). Sensory analysis for consumer acceptance and juice extraction yield of wheatgrass, barley grass and oat grass juices. International Journal of Innovative Research in Science and Engineering 3(12): 407-413

Rexhepi-Hasani, A., Renata, K. (2015b). Consumer Acceptance and Readiness to Pay for Green Juices Containing Grain Grass Juices in Kosovo. Journal of the Association-Institute for English Language and American Studies 4(6): 49-57

Sánchez-Moreiras, A.M., Weiss, O.A., Reigosa-Roger, M.J. (2004). Allelopathic evidence in the Poaceae. The Botanical Review 69(3): 300319

Sezgin, C. (2020). Tahılların çimlendirilmesi ve buğday çimi. https://www.canfezasezgin.com/Home/Icerik/Tahillarin-cimlendirilmesi-vebugday-cimi, (Erişim Tarihi: 21.07.2020).

Stratu, A., Toma, D., Costica, N. (2012). The effect of extracts from Apium graveolens L. and Evisticum officinale koch leaves on the germination of certain dicotyledons species. An. Stiint. Univ. Al. I. Cuza Iasi, Sect. II a. Biol. Veget., 58(2): 73-79

Tabur, S., Demir, K. (2008). Tuz Stresi Altındaki Mitotik İndeks ve Kromozom Anormallikleri Üzerine Triakontanol Ön Uygulamasının Etkileri. Research Journal of Biology Sciences 1(1): 11-15.

Terzi, İ. (2007). Ceviz meyve kabuğu özütlerinin kavun tohumlarında çimlenme, fide uzaması ve kuru ağırlık üzerine etkileri. Anadolu Üniversitesi Bilim ve Teknoloji Dergisi, 8(2): 355-360

Yurttaş Kılınç, C. (2015). Bazı allelopatik bitki özütlerinin farklı yabancı ot tohumlarının çimlenmesi üzerine etkisi. (Yüksek Lisans Tezi) Selçuk Üniversitesi Fen Bilimleri Enstitüsü, Konya

Zeng, R.S., Mallik, A.U., Luo, S.M. (2008). Allelopathy in Sustainable Agriculture and Forestry. Springer Press, New York 